T H E

Botanical Gazette NOVEMBER 1914

\title{
PRAIRIE VEGETATION OF A MOUNTAIN-FRONT AREA IN COLORADO
}

A R THUR G. VESTAL

(WITH NINE FIGURES)

This account is based on a study, during the past three seasons, of plant associations in the Great Plains region and of their modifications along the mountain-front. These are caused by climatic, physiographic, and vegetational differences which are of influence immediately adjoining the foothills, and to a less degree within a "mesa" belt extending eastward for several miles from the mountains. The study was carried on chiefly in the neighborhood of Boulder, Colorado. The area under particular consideration may be seen in the map (fig. I). The mesas at Colorado Springs, slightly more arid than those at Boulder, have been studied by Shantz (I7). A mountain-front area in New Mexico has recently been described by WATSON (20). Vegetation of the open plains has been studied principally by Pound and Clements (13), and by SHANTZ (18).

\section{The region}

The structure of the Great Plains is well described by JoHnson (ro, especially pp. 627, 628). They are essentially a structural rock slope, covered by débris from the Rocky Mountains. Near the mountains the débris apron is a mixture of rock fragments of all sizes; it has been removed in places by erosion, exposing the shales or sandstones beneath, with their residual soils. The 

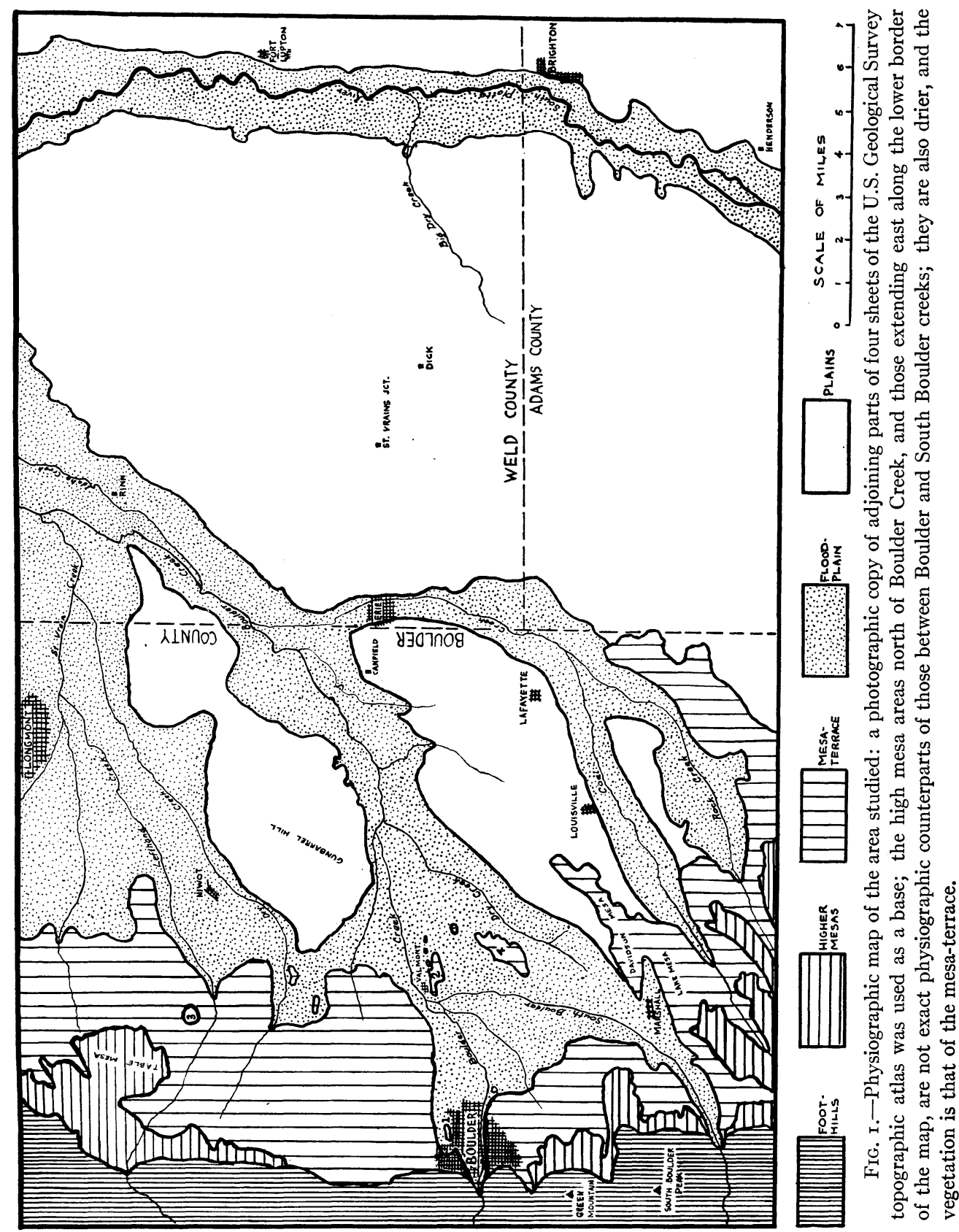

This content downloaded from 128.143.023.241 on August 09, 2016 19:54:49 PM All use subject to University of Chicago Press Terms and Conditions (http://www.journals.uchicago.edu/t-and- 
uneroded areas are left as elevated benches, locally called mesas, which have been described by LEE (II) and which are discussed also by Fenneman (4) and by Dodds (3). The physiographic divisions of the region are shown in the map (fig. 1 ); they are as follows:

I. The foothills, with their hogback ridges and upturned crags, locally quite variable in soil, exposure, slope, etc.

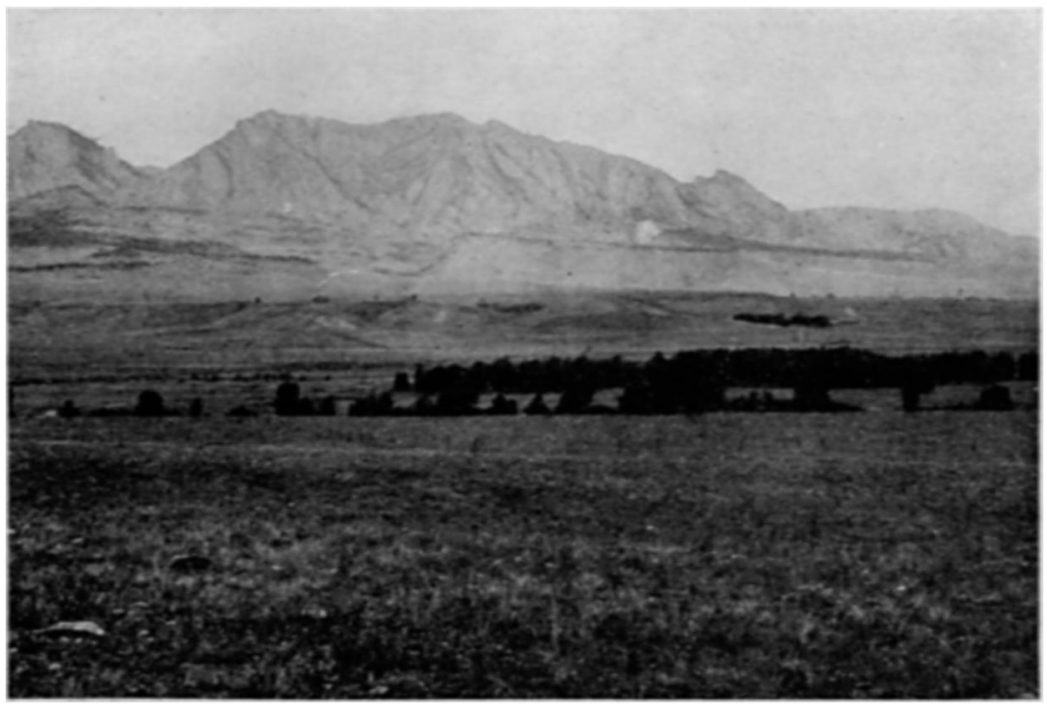

Fig. 2. -Green Mountain and its mesas: in the foreground the mesa-terrace level occupied by a modified short-grass growth; next the floodplain of South Boulder Creek; next a continuation of the mesa-terrace; above that the higher mesa level, interrupted, with long slopes, and graded tops partly covered with pines; October 1913.

2. The mesas of the older and higher level, not continuous along the mountain-front. surface.

3. The mesa-terrace, a more extensive, lower, and more recently graded

4. The floodplain, of the present and still lower stream grade, generally débris-covered as the two mesa levels.

5. The plains proper, usually separated from the mountain-front, and with generally fine soil, residual or aeolian.

The first four divisions may be distinguished in fig. 2 .

A mesa may abut at its head upon the higher slopes of the foothills or of a mesa of a higher level, or it may be isolated, cut off by 
erosion. Vegetation of cut-off mesas more closely approximates that of open plains. The physiographic parts of a mesa are four:

I. The mesa-top, flat, slightly inclined (at the angle of the stream gradient), and covered with unassorted rock waste. An exposure of the detritus cap is shown in fig. 3 .

2. The mesa-crest, either abrupt, with loosely strewn surface rocks, and coarse, dry, unstable surface soil; or gently rounded, with soil conditions as on the mesa-top.

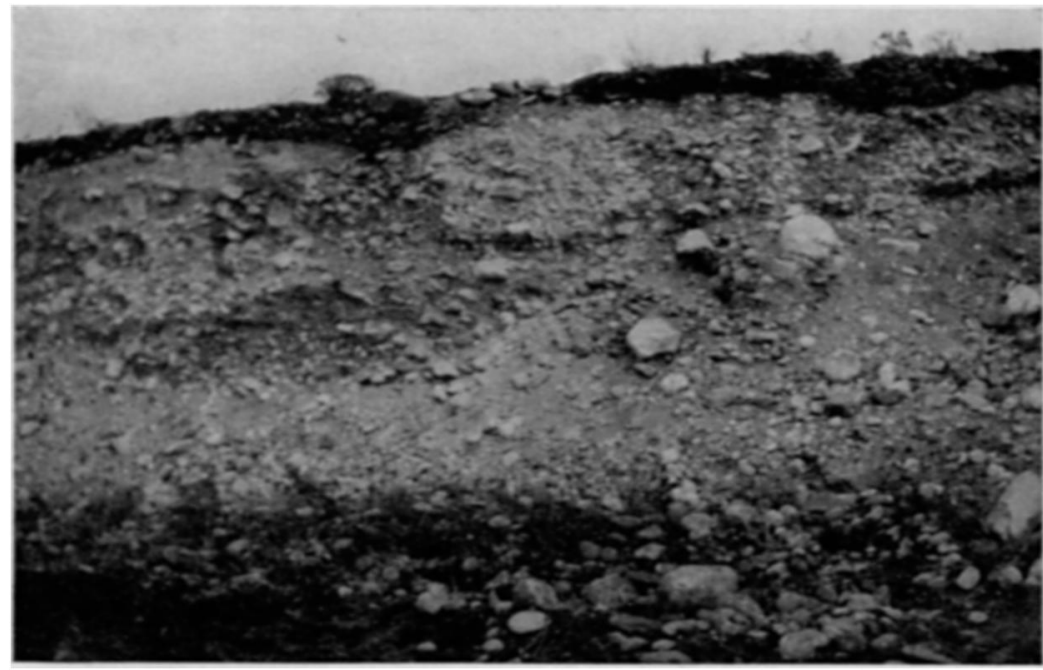

Fic. 3. - Vertical exposure of the detritus cap of a remnant of mesa-terrace four miles east of Boulder: the layer of mixed soil is about twelve feet deep; the surface layer is darker; the substratum is Fort Pierre shale; 1912.

3. The side-slope, either actively eroding or stable. If the slope has been lowered below the bottom of the mesa-cap, the soil of the slope is usually derived from the substratum, with only a few surface rocks. Otherwise, soil conditions are similar to those of the mesa-top. Seepage areas just below the crest are infrequent.

4. Valleys or draws, originating on the side-slope, usually broad and shallow. Gullies are infrequent. $V$-shaped ravines, with intermittent streams, are present in the higher mesas. Surface soil is usually fine grained.

Climatic influences within the region have been studied by RaMaley (14) and RobBins (15). Only a brief summary from these two papers is given. Climatic variation from east to west is 
probably very abrupt at the mountain-front, although actual data are extremely scanty. The mean annual rainfall at Boulder is I8.46 inches. At Brighton (see map) the annual rainfall is about 4 inches less; on the upper mesa level it is higher than at Boulder. The months of greatest precipitation are April and May. Evaporation is on the whole rapid, less so at the foothills. The mean annual temperature at Boulder is $5 \mathrm{I}^{\circ} \mathrm{F}$. Temperature variations are more extreme on the mesa-terrace than on the higher mesas, the plains having a still more severe climate. Temperature inversion is a local factor in reducing diurnal temperature variations in the mesas. The growing season is thus longer at the mountain-front; spring plants appear here several weeks earlier than on the plains some miles to the east.

\section{Diverse character of the vegetation}

In the open plains, as discussed by Shantz (18), the plant associations are well defined, and their relations to soil and topography have been clearly distinguished. Near the mountains, however, associations are more numerous, are variable, mixed in character, not definite. The following conditions are suggested as tending to complicate the character of the vegetation:

I. Climatic conditions undergo a transition at the meeting line of plains and mountain regions. The average climate for the mesa zone, if such a term can be used, is thus intermediate in character.

2. Annual fluctuations in climate are here unusually great, favoring alternately mountain and plains vegetation.

3. Rainfall during April and May is adequate for mesophytic prairie-grass vegetation, while the latter part of the summer is usually dry. Less xerophytic foothill plants are conspicuous in the mesa areas during the vernal period; later, xerophytes of plains and dry prairie-grass predominate.

4. Variability of soil conditions (soil texture, moisture content, run-off, and absorption) is considerable and is extremely local, the usual mesa soil being composed of unsorted rock fragments of all sizes. Mesophytes can grow immediately beside and from under surface bowlders. Local and extreme variability in character of vegetation is thus possible. Radically different plants, as regards growth-form and physiological constitution, occur frequently in the same growth.

5. Topography is considerably and very locally diversified.

6. Opportunity for invasion by mountain plants is very good. 
7. Environmental conditions are on the whole severe; the vegetation is in large part open. Open associations are less definite in plant composition than closed associations, in which plant competition has exercised more of a selective influence (cf. footnote below). Different associations are thus as likely to intergrade as to alternate sharply, the more so since environments frequently pass gradually one into another.

8. Present tendencies toward stabilization of mesa vegetation are more or less obscured by artificial factors, chief of which is grazing.

The principal effect of these complicating agencies is the presence of mixed growths of all grades. Mixed associations are frequent, in which plants normally dominating different associations occur together. The various secondary species also are not so regularly associated with particular dominants as would be expected from the study of more nearly typical representations of these same associations in other parts of the prairie region. At present an arrangement of the minor growths and variations of associations must be tentative. The associations are characterized partly from their occurrence and composition in other parts of the prairie province, and while certain growths in the mesa area are typical in composition, the best that can be done at present with certain growths within the area is to regard them as mixtures of two certain associations, or as a representative of one association varying in the direction of another, or with an added plant element from some particular source. On the other hand, certain appearances of some of the associations $\mathrm{s}^{\mathrm{I}}$ are quite definite in composition, quite regular and uniform in occurrence in different stations of the mountain-

${ }^{1}$ Definitions of terms applied to plant growths of different rank, as herein used, may conduce to accuracy. The unit of vegetation is taken to be the plant association, meaning an essentially uniform assemblage of plants living together in an area essentially uniform in environmental conditions. No interrelationship of different plants is necessarily implied, nor is uniformity taken to exclude internal local variability of either environment or vegetation. Those who have worked principally with closed vegetation in the humid eastern states are likely to formulate certain attributes of plant associations which will not apply to open growth in the less favorable environments of semi-arid regions, or to primitive stages in development of vegetation, or to mixed growths in habitats internally variable. In areas of vegetation permanently or temporarily open, plant competition is usually not an important limiting factor; there is no competition for light as in forest, and very little for above-ground space as in closed grassland; root competition is perhaps not so general as accommodation of root systems, so that different plant species derive moisture from different soil depths. Physical conditions may thus exert more direct control upon plant indi- 
front, and often definitely to be correlated with particular environmental features.

\section{Synopsis of the associations}

The following associations, with the exception of several of the local growths, are typical within, and usually restricted to, the generally treeless interior region of North America, which is characterized by low winter rainfall and grassland vegetation (Prairie Province, Pound and Clements I2; Gleason 5, p. 43). Practically all the associations are considerably variable in composition over their range, which in most cases is extended. No single criterion has been depended upon in classifying the associations. ${ }^{2}$

Associations of extended and general distribution within the area of the province; established vegetation, relatively stable or permanent, occupying the more extensive habitats provided by climate and physiography (Climatic or Major Prairie Associations).

Growth dominated by surface-rooted grasses, extensive in the more arid western part of the province, or Great Plains region.

Dominant plants of low mat form (the short-grass growth-form of gramagrass and buffalo-grass).

Short-Grass Association

Dominant plants taller (wheat-grass); growth extensive in northern parts of the plains region, and extending southward locally along the mountain front.

Wheat-Grass Association

viduals. It seems advisable at present to make our concept of the plant association quite broad, and to recognize that there are different types of associations.

A consocies, as here used, refers to an appearance or representation of an association characterized by one or several of its dominant species. English ecologists use facies in the sense that consocies is here used. A society of an association is taken to mean a representation of an association distinguished by abundance of one or several secondary species, using the word secondary to include "principal" and "secondary" species. Certain ecologists would use society in the sense that consocies is here used, preferring to use consocies as synonymous with association, reserving the latter term for referring generically to plant growths in general. The writer prefers to distinguish between growths characterized by dominant species and those named for secondary species, by calling the first a consocies, the second a society. It is apparent that there are a number of different kinds of societies. The present use of consocies is that of Gleason (5), who gives criteria (p. $3^{8}$ ) for determining whether two growths represent distinct associations or two consocies of the same association.

2 The associations within a particular region form a complex, which may be classified in different ways, according to the purpose of the study. Bases of classification have been discussed by the writer (Local distribution of grasshoppers in relation to plant associations. Biol. Bull. 25:150. 1913). 
Growth dominated by usually deep-rooted grasses; more extensively developed in the less arid central and eastern parts of the province, or Prairie region, and of local distribution along the mountain-front.

Dominant plants of tuft growth-form (of the Andropogon type); many of the secondary species pronounced xerophytes; growth most extensively developed in the central part of the prairie region.

Bunch-Grass Association

Dominant plants close-growing mesophytic grasses, usually sod-formers (of the nature of Poa pratensis); secondary species composed of a larger proportion of mesophytes; most extensively developed in the eastern part of the prairie region, particularly along the forest border.

Prairie-Grass Association

Associations of local, though commonly wide, distribution within the area of the province; either established or primitive stages of vegetation; frequently not restricted to the area of the province (Minor Associations).

Associations typical of habitats representing extreme conditions within the area of the province, in which local physical conditions, not being in accord with climatic conditions, determine the character of the vegetation to a large extent. The growth is thus as stable and permanent as the physical environment (Local or Edaphic Associations).

Associations of rock or of non-alkaline soils.

Growth of rock surfaces; well developed only in the foothills.

Associations of dry soil.

Lichen Association

In stony or gravelly habitats, as buttes, rock ridges, and exposed mesacrests.

In the most extremely xerophytic and stony habitats; dominant plants cespitose, prostrate.

Mat Association

In less extreme habitats of coarse or loose soil; dominant plants xerophytic grasses.

Stipa-Aristida Association

In sandy soil; not well represented within the area studied.

Sand-Hills Mixed Association

Associations of soils of high water content.

In moist soils, usually bordering depressions.

In wet or submerged soils.

Hordeum jubatum Association

Associations of saline or alkaline soils.

Swamp Associations, etc. 3

In deep dry alkaline soil, frequently sandy; growth dominated by tall xerophytic shrubs.

Chrysothamnus-Sarcobatus Association

${ }^{3}$ Swamp associations, dominated by species of Typha, Scirpus, Calamagrostis, Spartina, etc., are about the same within the region studied as in other parts of the United States, and are not here discussed. 
In clay or loam, sometimes subjected to flooding (margins of reservoirs, alkali flats).

Salt-Grass Association

Associations not typical of particular habitats, but scatteringly distributed chiefly because they are primitive growths; early stages in development of vegetation; growths typical of recently denuded or broken surfaces, or of physiographically new environments. Vegetation temporary in character; usually tending to change more rapidly than physical environments (Primitive Associations).

Growth dominated by annuals; short-lived growths typical in recently disturbed areas.

Plains Ruderal Association

Growths dominated by perennials; frequently preceded by a ruderal stage; usually less temporary in character.

Dominant plants xerophytic bunch-grasses.

Primitive Bunch-Grass Association

Dominant plants bushy xerophytes, deep-rooted, not grasses.

Gutierrezia-Artemisia Association ${ }^{4}$

\section{Descriptions of the associations}

The descriptions of associations are necessarily brief. Only the very important variations of each association are mentioned, and only dominant or very characteristic plant species receive notice. References to the same growths, or different representations of these same growths, as described by various authors, are given. It is the opinion of the writer that the time has come for correlation of associations in different parts of the same region, in cases in which the region is fairly well known. Effort has been made to select the more important references to prairie associations, but not to make a complete synonymy of the various growths.

\section{THE SHORT-GRASS ASSOCIATION}

Buffalo-grass formation.-Pound and Clements r 3, p. $35^{\circ}$.

Bouteloua (grama-grass) formation.-SHANTZ 17, p. 26.

${ }_{4}$ The Gutierrezia-Artemisia association, while most frequent in gravelly mesatops, is a primitive growth rather than an association of this particular habitat. In such situations the growth normally develops into short-grass. On the other hand, certain appearances of the Stipa-Aristida association (the wire-grass association of SHANTz, see p. 394), may be, following conditions of disturbance, a primitive association. Local associations, or growths relatively permanent in extreme habitats, may become primitive or temporary associations in the less extreme habitats in which climatic associations are dominant except for a short time after disturbance. Though primitive and local associations cannot always be rigidly separated, it seems helpful to distinguish the two groups. 
Grasslands of the high plains.-BRAY I, p. 9r.

Grama-buffalo-grass association.-SHANTZ 18, p. 24.

Grama-grass association.-ShanTZ I8, p. 2 I.

Grama-grass formation.-HARShBERger 7, p. 537 (after Pound and Clements).

Buffalo-grass formation.-HARShberger 7, p. 528 (after Pound and Clements).

The short-grass association in its typical form (BoutelouaBuchloe consocies), as developed on the open plains, has been well described by Shantz (18). The eastern half of the Boulder region is covered principally by this growth. Near the mountains the buffalo-grass (Buchloe dactyloides [Nutt.] Engelm.; Bulbilis dactyloides [Nutt.] Raf.) is very scantily represented, as also in the northern part of the plains region. Its scarcity is made up by increased abundance of the grama-grass (Bouteloua oligostachya [Nutt.] Torr.), which dominates much of the area. It forms either a pure or nearly pure growth (Bouteloua consocies), or, in the coarse soil of the mesa-terrace, enters into a mixed growth (Bouteloua mixed consocies). This growth is characterized by abundance of the deeper-rooted perennial plants of the plains region, as Euphorbia robusta (Engelm.) Small, Psoralea tenuiflora Pursh, Aragallus Lambertii (Pursh) Greene, and Grindelia squarrosa (Pursh) Dunal; and usually there are additional vegetational and floristic elements: (I) some few deeper-rooted grasses; (2) tall composites, legumes, etc., typical in the more xerophytic prairie-grass just east of the plains region; and (3) less xerophytic plants from the foothills (species of Pentstemon and Mertensia, Eriogonum umbellatum Torr., Geranium Parryi [Engelm.] Heller, etc.). Certain of these, as the last two, are rarely found except at the base of surface rocks. Here also are found occasional bunch-grasses, and shrubs from the foothills, as Ceanothus, Prunus, Oreobatus, marking invasion of foothill shrub associations. The vegetation of the mesa near Colorado Springs, described by Shantz (I7) is in large part to be assigned to the Bouteloua mixed consocies. A rather dry representation of this growth is seen in the foreground of fig. 2 .

The different growths dominated principally by Bouteloua are considered to be parts of the same association, rather than different associations, for the resemblances appear to be more constant and 
striking than the differences. The Bouteloua mixed consocies, presenting the most radical departure from the typical short-grass growth, is different mainly in the possession of a derived element. Local patches of pure short-grass are still present, and the mesophytic plants are found in very local spots differing in moisture conditions, due to the extreme mixture of all sizes of soil constituents.

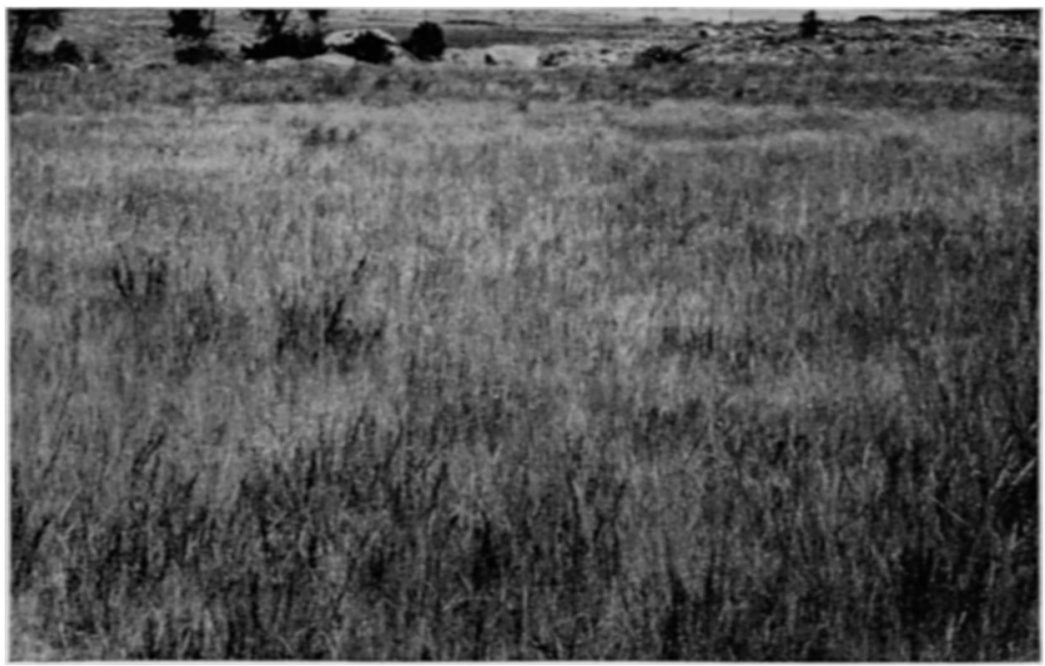

Fig. 4-Wheat-grass, with Artemisia aromatica (the dark plant) in fine-grained soil of the mesa-terrace just south of Boulder; June rgr3.

\section{THE WHEAT-GRASS ASSOCLATION}

Wheat-grass association.-SHANTZ 18, pp. $21,48$.

Agropyron formation.-Pound and Clements 13, p. 383.

Agropyron occidentale consocies.-SHANTZ 17, p. 36.

Agropyron growth of prairie crests.-HaRVEY 8, p. 279.

The wheat-grass (Agropyron Smithii Rydb.; Agropyron occidentale Scribn.) is established in rather looser clay soil than that in which the short-grasses dominate. The typical habitat is the deposition area at the base of side-slopes of mesas, with fine soil washed down from above. Recently disturbed clay and what appear to be areas of wind deposition are also occupied by wheat-grass. Invasion by grama-grass is often initiated, and the intermediate 
growth in which Agropyron and Bouteloua occur together is frequently seen. In the pure wheat-grass, Astragalus goniatus Nutt. and Artemisia gnaphalodes Nutt. together form one very definite society, while Tium Drummondii (Dougl.) Rydb. (Astragalus Drummondii Dougl.) characterizes a second. A third (fig. 4) is marked by Artemisia aromatica A. Nels. Carex stenophylla Wahlenb. and $C$. pennsylvanica Lam. dominate very small areas, usually within the wheat-grass association.

The wheat-grass association has very general distribution in northern parts of the Great Plains region, extending locally southward along the foothills. These interrupted growths would probably occupy a much larger area but for the influence of grazing, which appears to favor succession of wheat-grass by grama-grass.

\section{THE BUNCH-GRASS ASSOCIATION}

Bunch-grass association.-Shantz . 18, p. 54. Eastern Colorado. High prairie.-Hall 6, pp. 30-35, in part. Eastern Kansas. Andropogon-Sorghastrum growth.-Hiтcнсоск 9, p. 64. Eastern Kansas. Bunch-grass formation.-Pound and Clements I3, p. 354. Nebraska. Texas.

Grasslands of the semi-humid black-soil prairies.-BRAY I, p. 86, in part.

Andropogon growth of ridges, etc.-Harvey 8, pp. 287, 288. South Dakota.

Bunch-grass association.-GLEASON 5, p. 47, in part. Illinois.

Dry prairies of the prairie-grass formation.-HARSHBERGER 7, p. 523 (after Brendel 2, p. 34). Central Illinois.

Bunch-grass formation.-Harshberger 7, 532 (after Pound and ClemENTs). Nebraska.

The bunch-grass association, though occupying a very small part of the area studied, appears to be similar in composition to bunch-grass growths over the extent of the prairie province. It is best seen near the outer ends of the tops of the higher mesas south of Boulder (mixed bunch-grass consocies). The soil is gravelly, the growth somewhat open, about 35 per cent of bare surface being exposed. A number of species dominate together, in about the following order of importance: Andropogon scoparius Michx., Koeleria cristata (L.) Pers., Andropogon furcatus Muhl., Sorghastrum nutans (L.) Nash, Muhlenbergia gracilis Trin., Atheropogon curti- 
pendulus (Michx.) Fourn. (Bouteloua curtipendula [Michx.] Torr.). Secondary species include other grasses, rather xerophytic prairie perennials, as Liatris punctata Hook., Gaillardia aristata Pursh, Psoralea tenuiflora Pursh, Aster Porteri Gray, and Chrysopsis villosa Nutt. The growth is shown in fig. 5 .

The bunch-grass association depends upon a constant water supply which endures through the latter part of the summer. As available soil moisture is constantly present in mesa-terrace

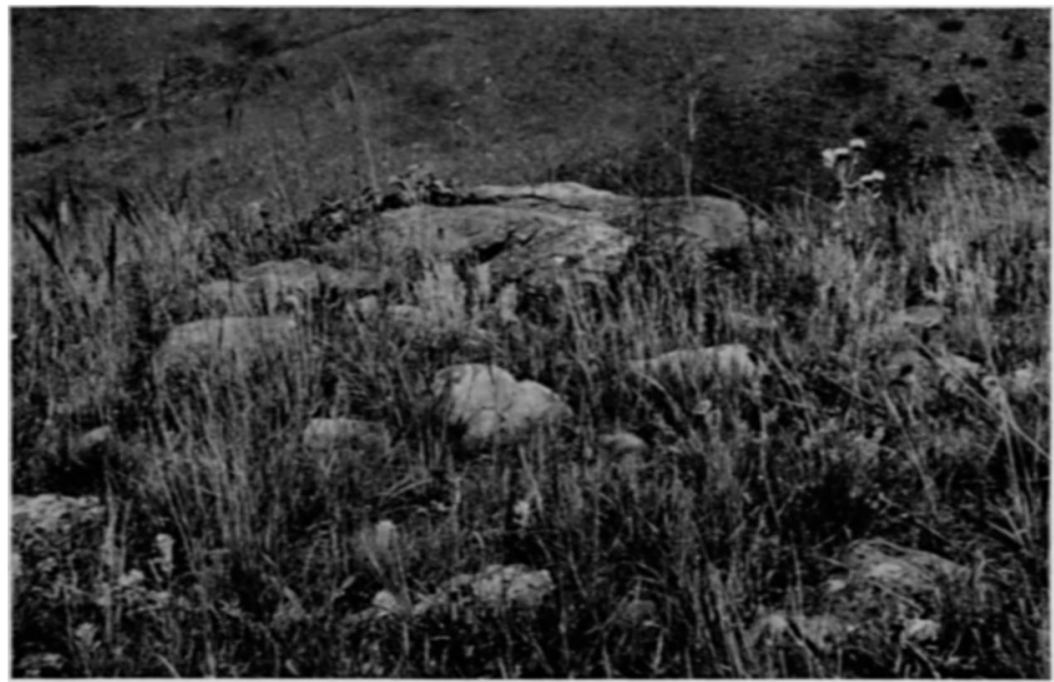

Fic. 5.-Bunch-grass at the south crest of Horse Mesa (of the higher level): Andropogon, Sorghastrum, Artemisia, Carduss; next to the large rock a shrub of poison ivy; on rock surfaces, lichens; September 1913.

soils only till the middle of July, the association is limited to moist slopes, the higher mesa-tops, and small depressions. Scattered bunch-grasses occur beside surface rocks in the mesaterrace.

The Andropogon furcatus consocies is a pure or nearly pure growth of the big blue-stem. It is found in local areas of coarse soil. There is also the Andropogon scoparius consocies, which is synonymous with the bunch-grass association of SHANTZ (18, p. 54). The occurrence of a practically closed bunch-grass growth, made 
up of Andropogon furcatus and Sorghastrum nutans, in fine-grained moist soil of stream bottoms in the floodplain, should also be noted. ${ }^{5}$ It probably formerly occupied considerable areas.

\section{THE PRAIRIE-GRASS ASSOCIATION}

Prairie-grass formation.-Pound and Clements r 3 , p. 348, in part.

Prairie-grass formation.-Shantz 18 , p. 23, in part.

Prairie-grass formation.- HARVEY 8 , in part.

Prairie-grass formation.-HaRshberger 7, pp. $5^{22,527}$, in part.

Prairie-grass associations.-Vestal 19, pp. 354, 355 .

The prairie-grass growth within the region is mesophytic, meadow-like, in spring, becoming quite dry in late summer, most of the plants being then dead. It is typically developed in rich black soil of fine texture, of high moisture content in spring and early summer. Such soil is regularly found in alluvial lower slopes of foothills and higher mesas.

The Poa-Koeleria consocies is dominated by Poa Buckleyana Nash and by Koeleria cristata (L.) Pers. Stipa viridula Trin., Poa pratensis L., Agropyron violaceum (Hornem.) Vasey, and Agropyron Smithii Rydb.are occasionally present. The growth is tall and close. In alluvial fans at the base of certain slopes, facing to the north usually, the Arnica society of the prairie-grass growth is developed (fig. 6). It is characterized by abundance of Arnica monocephala Rydb. (Arnica fulgens Pursh, in part). The Delphinium-Cerastium society is a growth in which Delphinium Nelsonii Greene and Cerastium campestre Greene are very conspicuous. There are several other well defined societies.

The Stipa viridula consocies is dominated by Stipa viridula Trin., with occasional other grasses. It is usually on the outer

5 The occurrence of bunch-grass in such different habitats as its mesa and floodplain stations bears out the view that the plant growth itself, rather than the habitat, should be used in delimitation of associations within even such a small area as the one studied. The resultant conditions essential to the plant growth, that is, continually available moisture, are fulfilled in both situations. Shantz has shown (18, p. 55) that the Andropogon scoparius consocies is found in gravelly soil near the mountains, in sand and loose loam in eastern Colorado, in Fort Pierre clays in South Dakota, and in loam soil in the eastern part of the prairie region. Probably the vegetation itself is a very good expression of the resultant of climatic, local, and historic factors; the complete environment. 
slopes of the foothills. Narrow zones of this growth are frequently found bordering Symphoricarpos and Prunus shrub associations of the foothills, which appear to be increasing in area on the slopes, at the expense of the grassland. In such meadow-like zones are seen Frasera speciosa Griseb., Thermopsis divaricarpa A. Nels., Achillea lanulosa Nutt., and Aster Geyeri (Gray) Howell, with other conspicuous mesophytes. Such meadow-like zones border scrub

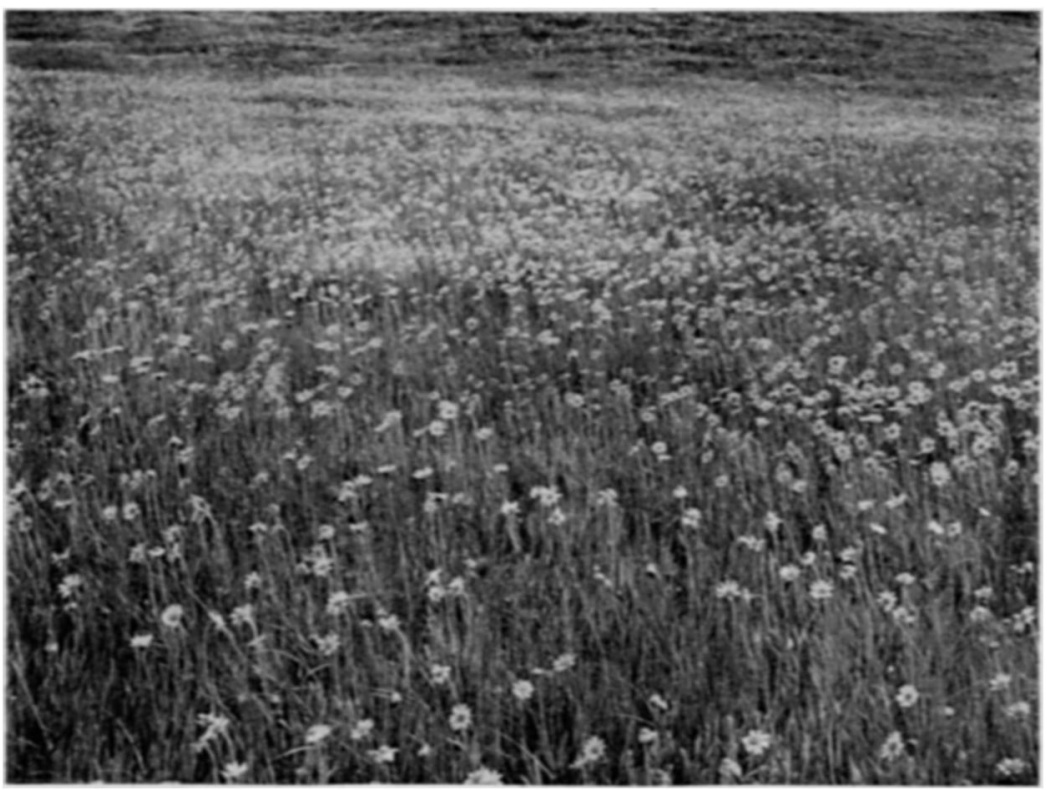

Fig. 6.-Society of Armica, in a prairie-grass growth of moist alluvium at the base of a steeper slope, south of Boulder; dominant plants are Poa and Koeleria; May I913.

oak associations farther south, at Castle Rock, Perry Park, near Larkspur, and at Palmer Lake.

The prairie-grass locally found west of the plains belt has many features in common with eastern black-soil prairie as represented along the border of the eastern deciduous forest. The secondary species, however, are mostly different, and the growth found along the mountain-front would probably be considered a separate association, which may be called the western mesophytic prairie-grass 
association. It may perhaps intergrade with the prairie-grass of the middle part of the prairie region. The growth on what is called the Middle Mesa (fig. 7) is intermediate between shortgrass and prairie-grass; it is floristically quite like the South Dakota prairie-grass described by Harvey (8). This similarity is more evident in late summer, xerophytic prairie-grass species

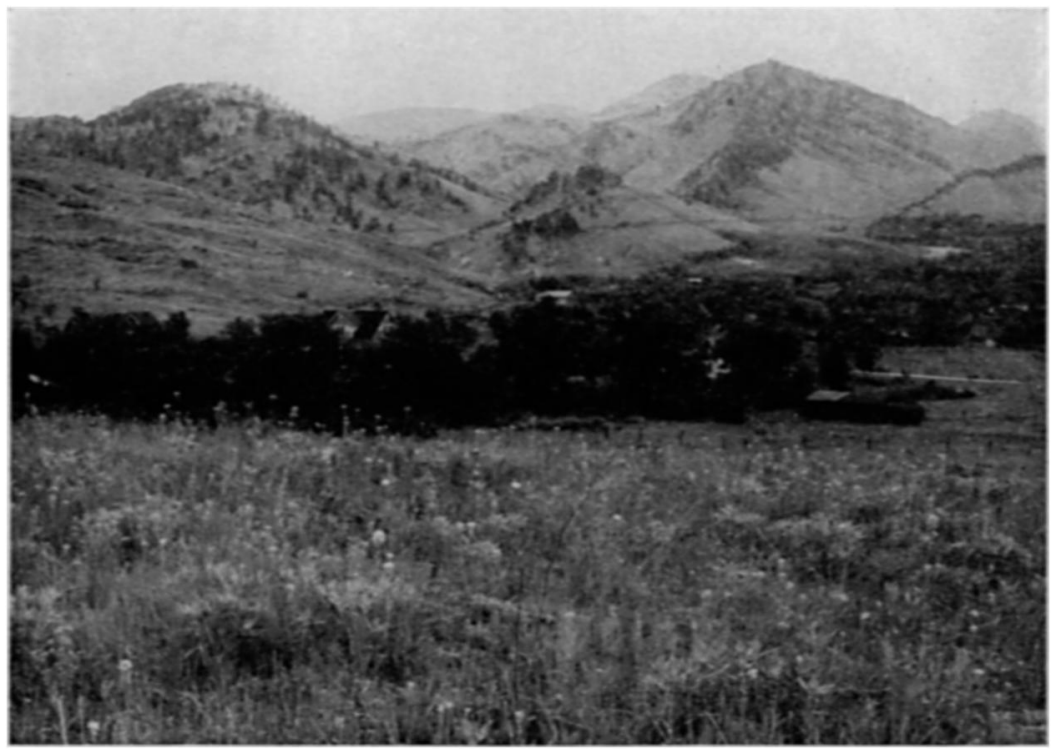

Fic. 7.-Mixed growth of the Middle Mesa, on the outskirts of Boulder: Koeleria, Stipa, Helianthus, Senecio (the flat-topped heads), Erysimum, Aragallus, Eriogonum alatum (the tall dead stalk), Eriogonum umbellatum; in the middle ground, the valley of Boulder Creek (the trees are planted in the town); above, the foothills, generally grass covered, with scattered rock pines, which are more abundant on the rocky ridges; June I, 1913.

like Solidago rigida L., Sideranthus spinulosus (Pursh) Sweet, Helianthus, Petalostemon, and Aster spp. being very conspicuous. The dominant grasses are the same in both Colorado and South Dakota areas. The dry prairies in east and west show considerable similarity; the more mesophytic prairies of east and west show considerable divergence, so far as species composition is concerned. 
THE LICHEN ASSOCIATION

Lichen formation.--SHANTZ I7, p. I88.

Lichen formation.-SHANTZ I8, pp. 22, 62.

The lichen growth on rock surfaces contributes an element to the vegetation of detrital soils of the higher mesa and mesaterrace levels within the region. Surface rocks are present on practically all the mesa-tops. The dominant species, as given by $\operatorname{Shantz}(\mathbf{1 7}, \mathbf{1 8})$ are Parmelia conspersa (Ehrh.) Ach., Rinodina oreina (Ach.) Mass., Lecanora calcarea (L.) Nyl., and Lecanora subfusca allophana Ach.

\section{THE MAT ASSOCIATION}

Mat formation of buttes and cliffs.-Pound and Clements r3, p. 376.

Mat formation of buttes and cliffs.-Harshberger 7, 535 (after Pound and Clements).

The open growth of dwarfed perennials which occupies sterile gravelly stations should perhaps not be regarded as a separate association; it is, however, distinctive in growth-form, and is frequent and well defined on buttes and hogbacks of northeastern Colorado, eastern Wyoming, and western Nebraska. It is physiologically similar to the Bouteloua hirsuta growth, and to the Artemisia frigida consocies, sometimes being found with these (fig. 8), not, however, in extreme conditions of coarse soil and exposure to sun and wind, as on certain abrupt mesa-crests. A number of the species are found also in gravel slide growths of the mountains. These growths have been studied by Clements, and by Schneider (I6), and are akin to the mat growths of stony habitats of the plains, in several respects.

Distinctive plants of the mat association are: Townsendia exscapa (Rich.) Porter, Orophaca tridactylica (Gray) Rydb. (Astragalus tridactylicus Gray), Lesquerella montana (Gray) Wats., Paronychia Jamesii T. and G., Hymenopappus filifolius Hook., Gilia pinnatifida Nutt. Several species of Chrysopsis, Geranium Parryi (Engelm.) Heller, Oreocarya virgata (Porter) Greene, and Phacelia heterophylla Pursh are frequently present. 
THE STIPA-ARISTIDA ASSOCIATION

Stipa formation of high prairies.-Pound and Clevents 13, p. 381 .

Wire-grass association.-SHANTZ 18, p. 48.

The dominant plants of this growth are xerophytic grasses of tuft growth-form, with moderately deep roots. They are found usually in coarse sterile soil, more commonly on south-facing slopes and crests.

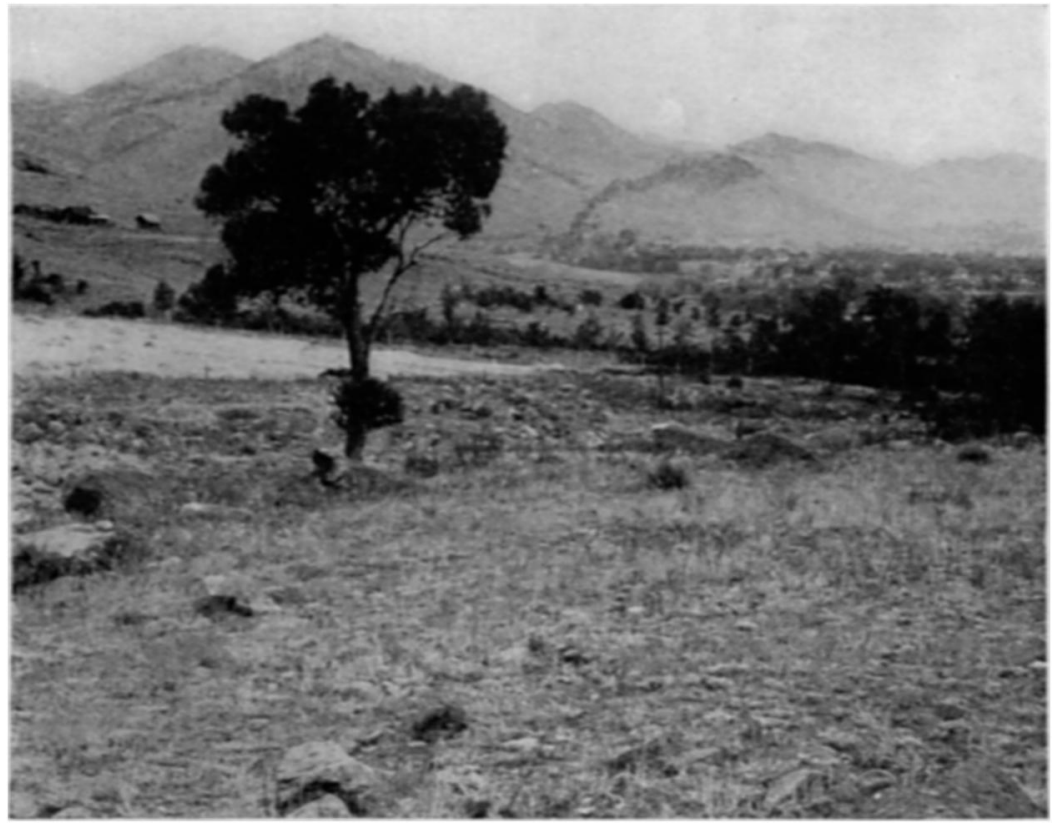

Fic. 8.-Primitive grassland on a gravelly terrace left by Gregory Creek, which lies across the picture in a slanting position, and is marked by the large tree, a narrowleaf cottonwood; the growth consists of Boutelowa kirsuta, Artemisia frigida, and a few mat plants, and is very open; July rgr 3 .

The Stipa comata consocies, dominated by Stipa comata Trin. and Rupr., occurs in the region on gravelly slopes and on windswept tops and crests of mesas. In it are occasionally found Chrysopsis villosa Nutt., Psoralea tenuiflora Pursh, Helianthus pumilus Nutt., Aristida longiseta Steud., and Sitanion breoifolium J. G. Smith. A pure growth of Stipa has been seen on a pebbly railroad embankment. 
The Aristida longiseta consocies is dominated by the wire-grass (Aristida longiseta). It is important (in sandy loam and broken soils) in parts of eastern Colorado and west-central Kansas and Nebraska (Shantz I8, p. 48). In the mesa area Aristida does not occur except in association with other grasses, chiefly Stipa comata. For the present the two growths have been considered together, on account of similar habitat preference, similarity of secondary species, and regularity of occurrence in association, at least in the region studied. More extended study may show the two growths to be representatives of different associations, which intergrade within the region.

\section{THE SAND-HILLS MIXED ASSOCIATION}

Sand-hill formations.-Pound and Clements I3, p. $35^{2}$, in part.

Sand-hills mixed association.-Shavtz 18, p. 58 .

Within the region studied no truly sandy areas of any extent have been found. Local areas of sandy soil occur with sandstone outcrops and in certain dry stream beds of the plains. The sandhills mixed association is perhaps not typically developed within the area, though well shown on sandy bluffs of the South Platte at Globeville, on the outskirts of Denver; the usual growth may be referred either to a variation of the short-grass mixed association, or to a primitive open growth made up chiefly of plant species abundant in sand-hills. Sandy soil may be recognized by the presence, often in abundance, of Mentzelia nuda (Pursh) T. and G., Abronia fragrans Nutt., Cleome serrulata Pursh, and Artemisia filifolia Torr. Yucca glauca Nutt. is often extremely abundant in sandy soil.

\section{THE HORDEUM JUBATUM ASSOCIATION}

A pure growth of the squirrel-tail grass (Hordeum jubatum L.) typically occupies moist soil of depressions, or a zone of moist soil, of variable width, surrounding swampy areas or standing water, or bordering gently sloping ditch banks. The growth appears to be native in such situations, and geographically widespread.

\section{THE CHRYSOTHAMNUS-SARCOBATUS ASSOCIATION}

Chrysothamnus growth of the sage-brush formation.-Pound and CLEments I3, p. 372 . 
Greasewood-white sage formation.-Pound and Clements r3, p. 374.

Chrysothamnus graveolens society.-SHANTZ I7, pp. 4I, 47 .

Bigelovia association.-WATSON 20, p. 200, in part.

Greasewood society of the Bigelovia association.-Watson 20, p. 202.

This growth occurs in deep alkaline soil which is usually more or less loose or sandy. Chrysothamnus graveolens (Nutt.) Greene (rabbit brush) is more abundant in loam; Sarcobatus vermiculatus (Hook.) Torr. (greasewood) is more abundant in sandy loam or sand; the two often dominate together. The lower slopes of the two Table Mountains at Golden are covered with a Chrysothammus growth. Sarcobatus, with or without Chrysothammus, is abundant in sandy stream bottoms farther south in the valley of the Arkansas River. With Chrysothamnus graveolens are often found Eurotia lanata (Pursh) Moq. and Chrysothamnus plattensis Greene. An open growth of the latter, usually mixed with the short-grass cover, is frequent in low ground of draws, in which the soil is finegrained and with a high proportion of soluble salts, or on level alkaline loose clay.

Within the Boulder area these growths are local, and not particularly well developed. They range locally through the plains region, and with similar growths, through the southwestern United States. The present arrangement in one association of the particular growths seen is tentative.

\section{THE SALT-GRASS ASSOCIATION ${ }^{6}$}

Salt-grass Orache formation.-Pound and Clements 13, p. 388, in part.

Two grasses, Sporobolus asperifolius (Nees and Mey.) Thurb. and Distichlis spicata (L.) Greene, either together or singly, are dominant plants in flats which are sometimes white with alkali. Within the region such flats occur on gently sloping margins of floodplain lakes and irrigation reservoirs, and in restricted stream bottom areas. Irrigation, as at present practised, tends to increase their number and extent. The soil may be clay or loam, is compact, often trampled by cattle, and frequen tly subject to occasional flooding.

${ }^{6}$ Vegetation of saline basins in the prairie region is discussed by J. H. SchaffneR in Notes on the salt-marsh plants of northern Kansas, Bot. GAZ. 25:255-260. I898. 
The sea blite (Suaeda diffusa Wats.) is occasionally found in similar habitats, though usually the clay is dry and loose. It may represent a distinct association of strongly alkaline or saline habitats, or perhaps a primitive growth of alkaline soil.

\section{THE PLAINS RUDERAL ASSOCIATION}

Open waste formation.-Pound and Clements i3, p. 4I 2 .

Plains ruderal formation.-ShANTZ I7, p. I82.

The first plants to invade disturbed ground in the area studied are annuals, practically all of the plains region. The more important species are Argemone intermedia Sweet, Euphorbia marginata Pursh, Solanum rostratum Dunal, Festuca octoflora Walt., Lappula occidentalis (Wats.) Greene, Plantago Purshii R. and S., Ambrosia psilostachya DC., Boebera papposa (Vent.) Rydb., Helianthus petiolaris Nutt. Ambrosia trifida integrifolia (Muhl.) T. and G. is a very conspicuous ruderal in moist soil.

Toward the mountains, and in all except the driest soils, the sweet clover (Melilotus alba Desv.) is becoming very frequent in disturbed situations. In such habitats, as in the eastern part of the prairie, it is apparently more successful than native ruderals. The Russian thistle (Salsola Tragus L.) behaves as if it were a successful native ruderal, having become thoroughly established.

\section{THE PRIMITIVE BUNCH-GRASS ASSOCIATION}

Calamovilfa longifolia consocies.-ShanTZ I7, p. 46.

Sporobolus cryptandrus (growth).-SHANTZ I7, p. 46.

Certain of the grasses of the prairie region are very abundant in new growths or in open or sterile situations, as contrasted with other grasses which are found only in more permanent, closed associations, or in mesophytic stations or in soils of considerable humus content. Among these xerophytic grasses distinctive in primitive growths are Elymus canadensis L., Eriocoma cuspidata Nutt., Calamovilfa longifolia (Hook.) Hack., Sporobolus cryptandrus (Torr.) Gray, and Panicum virgatum L. Stipa Vaseyi Scribn., though infrequent in the immediate area, occupies many similar situations throughout the Colorado mountain-front. All of these can grow 
in coarse soil, being deep-rooted; some of them build temporary dunes on the sand-hills and on the shores of the Great Lakes. Each species occurs in places alone, but mixed growths of several of these grasses, are about as frequent, and since they are very similar in growth-form, in physiology, and in distribution, they are for the present considered as members of one variable association.

Within the region these growths occur in scattered patches in disturbed situations, frequently in railroad rights-of-way, and usually in loose or sandy soil. Extremely local growths are found on the higher mesas and foothill slopes.

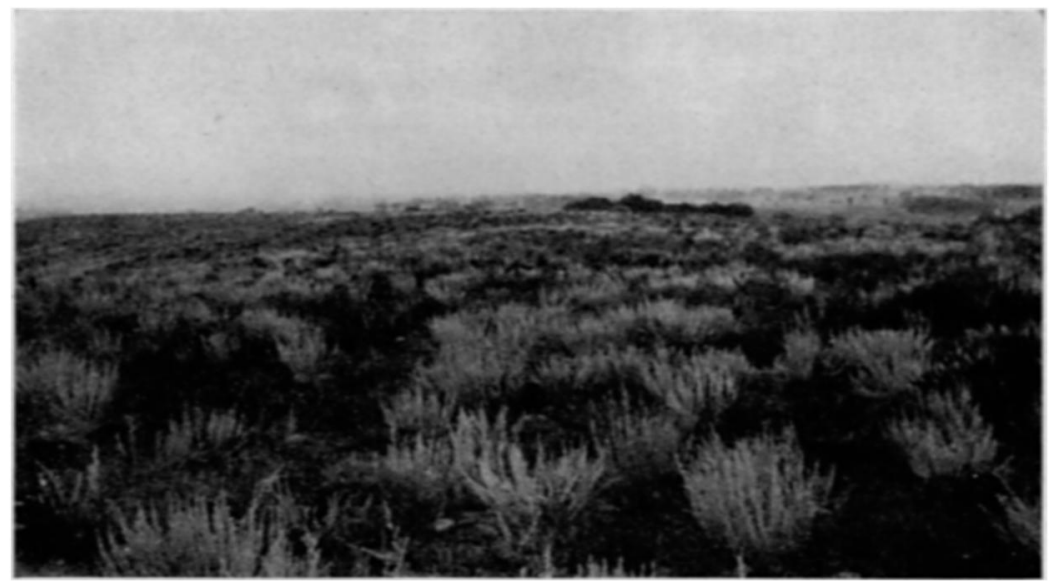

Fig. 9- Gutierresia-Arkemisia growth of a mesa four miles east of Boulder: this end of the mesa differs from the rest of it in that it is not at present pastured. and in that Gutiorresia is scarce; Eriogonum effusum is conspicuous, though not so in the photograph; September rgr2.

\section{THE GUTIERREZIA-ARTEMISIA ASSOCIATION}

Gutierrezia-Artemisia association.-ShaNTZ 18, p. 60.

Undershrub formation.-Pound and Clements 13, p. 371 , in part.

Artemisia frigida society.-SHANTZ 17, p. 37.

Gutierrezia Sarothrae society.-SHANTz 17, p. 37.

Gutierresia formation.-WATSON 20, p. 202.

The Gutierrezia-Artemisia association, described by SHANTz (18), is typically developed in the plains areas of the region studied. Gutierrezia Sarothrae (Pursh) B. and R. is more abundant in the 
southern part of the plains region, and is not common in the foothills or even in the mesa-terrace. Artemisia frigida Willd. ranges far to the north, and forms an important primitive growth in the mountains to as high as 10,000 feet. The Artemisia frigida consocies, therefore, is the important growth of the mountain-front, being quite frequent on talus slopes and gravel slides of the foothills. Bouteloua hirsuta Lag. is often associated with Artemisia; this growth may represent a separate association.

The Gutierrezia-Artemisia growth in the plains of the region contains Eriogonum effusum Nutt. and Grindelia squarrosa (Pursh) Dunal, sometimes abundantly. There are indications that relative abundance of Gutierrezia and Artemisia is materially influenced by grazing animals, Gutierrezia being apparently more resistant.

University of Chicago

\section{LITERATURE CITED}

I. BRAY, W. L., Distribution and adaptation of the vegetation of Texas. Bull. Univ. 'Tex. no. 82. pp. 108. Igo6.

2. BREndel, F., Flora Peoriana. The vegetation in the climate of middle Illinois. Peoria. 1887 .

3. Dopds, G. S., Geology and physiography of the mesas near Boulder. Univ. Colo. Studies 6:II-I9. I908.

4. Fenneman, N. M., Geology of the Boulder district, Colorado. U.S. Geol. Surv. Bull. no. 265. pp. ror. I905.

5. Gleason, H. A., The vegetation of the inland sand deposits of Illinois. Bull. Ill. State Lab. Nat. Hist. 9:23-I74. I9ro.

6. Hall, E., Notes on some features of the flora of eastern Kansas. Trans. Amer. Acad. 50:29-35. 1870.

7. Harshberger, J. W., Phytogeographic survey of North America. Die Vegetation der Erde 13: pp. 790. I9II.

8. HaRvey, L. H., Floral succession in the prairie-grass formation of southeastern South Dakota. Bот. GAz. 46:8I-108, 277-298. I908.

9. Hiтснсоск, A. S., Ecological plant geography of Kansas. Trans. Acad. Sci. St. Louis 8: $55^{-69}$. I898.

ro. Johnson, W. D., The high plains and their utilization. Ann. Repts. U.S. Geol. Surv. 2I, part 4. pp. 599-74I; 22, part 4. pp. 63I-669. I900, I90I.

II. LEE, W. T., The origin of the débris-covered mesas of Boulder, Colorado. Jour. Geol. 8: 504-5II. I900.

I2. Pound, R., and Clements, F. E., The vegetation regions of the prairie province. Вот. GAZ. 25:38I-394. I898. 
13. Pound, R., and Clements, F. E., The phytogeography of Nebraska. 2 d ed. Lincoln. pp. 442. I900.

14. Ramaley, F., Climatology of the mesas near Boulder. Univ. Colo. Studies 6:19-3I. I908.

15. Robbins, W. W., Climatology and vegetation in Colorado. Вот. Gaz. 49:256-280. I910.

I6. SCHNemer, E. C., The succession of plant life on the gravel slides in the vicinity of Pike's Peak. Colo. Coll. Publ., Sci. Ser. 12: no. 8. pp. 2893II. I9II.

17. Shantz, H. L., A study of the vegetation of the mesa region east of Pike's Peak: The Bouteloua formation. Bот. GAz. 42:16-47, 179-207. I906.

I8. - Natural vegetation as an indicator of the capabilities of land for crop production in the Great Plains area. U.S. Dept. Agric., Bur. Pl. Industry, Bull. no. 20I. pp. Ioo. I9II.

19. Vestal, A. G., A black-soil prairie station in northeastern Illinois. Bull. Torr. Bot. Club 4I: 35I-363. I9I4.

20. Watson, J. R., Plant geography of north central New Mexico. Bot. GAz. 54:194-2I7. I9I2. 